\title{
Gender, ICT and Millennium Development Goals for Sustainable Development in West Africa
}

\author{
Shikha Vyas-Doorgapersad \\ North-West University, Faculty of Economic Sciences and Information Technology \\ PO Box 1174, Vanderbijlpark, 1900, Republic of South Africa \\ Email: Shikha.VyasDoorgapersad@nwu.ac.za
}

\section{Doi:10.5901/mjss.2014.v5n21p405}

\begin{abstract}
The year 2015, the target date to achieve the Millennium Development Goals, is fast approaching, and it is now time to assess some significant landmarks. For example, to what extent is the gender component incorporated in MDGs? To what extent is MGD 3 (gender equality and women empowerment) progressing towards its full achievement in West Africa? Are West African countries committed enough to incorporate MDG3 in their national policies? How are MDG3 and MDG 8 (information and communication technologies) linked in the progress towards sustainable development? What measures are in place to achieve MDG 3 and MDG 8 for development at country-specific levels? To find answers to these pressing concerns, a descriptive and analytical approach is utilized here. Case studies, government reports and country-specific MDG reports are considered in order to deduce the relevant information. The findings reveal that there is a lack of gender-responsive ICT in West African countries. This article aims to provide policy recommendations to improve the situation.
\end{abstract}

Keywords: gender; women empowerment; information and communication technologies; sustainable development; Millennium Development Goals

\section{Introduction}

In many countries the argument is put forward that sustainable development and the needs of the community as a whole must come first, rather than "providing a preferential focus on women's development needs and their rights". However, as cited in Wikibooks (2013), this "ebb and flow of development priorities and choices ... has yet to fully integrate a gender perspective that is aimed towards the achievement of women's empowerment". A review of the literature in the field of gender studies and policy studies (Jensen, 1989; Balit, 1999; Hafkin and Taggart, 2001; Gillard et al, 2008) explores the nexus between gender, ICT and development. This linkage has raised global consciousness on gender analysis, gender disaggregated data, and the clear stipulation of roles and responsibilities to identify gender needs as development demands. These demands are apparent in the reasoning behind setting Millennium Development Goals to ensure sustainable social, economic and technological advancement worldwide. "Gender-sensitive ICT applications to education, health care, and local economies have helped communities progress toward the MDGs". Importantly, they also "facilitate rural health-care workers' access to medical expertise through mobile phones and the Internet". Dumas (2008:1) further explains that teachers are able to "expand learning resources through the Internet and satellite services, providing a greater knowledge base for learners ... although Internet access and landline numbers are still low" in Africa. This article explores the linkages between gender, ICT and MDGs establishing their impact on sustainable development in West countries.

\section{Gender and ICT: An Overview}

Gender is conceptually defined by various scholars and academics (Rubin, 1975; Molyneux 1985; Mackinnon, 1989; Moser, 1993; Lars, 2003; Dhoj, 2009; Cherry, 2013) as varied attributes linking to feminine and masculine aspects, namely differentiated roles and responsibilities, identity, attitudes, behaviour patterns, needs and requirements. In this context, both women and men deserve equal respect, opportunities and appreciation in any given society (Reddy, 2006, p. 28). This study is based upon the feminist aspect of gender; it explores the need for transformative divergence from welfare to the empowerment of women. The article therefore employs the "empowerment approach of feminist theory" (Govender \& Vyas-Doorgapersad, 2013, p.107) as a theoretical scaffold. The empowerment approach seeks "to make a place for itself among those new social theories that are attempting to connect the personal and the social, the individual 
and society, the micro and the macro" (http://www.mpow.org). The approach is also substantially useful to translate the "political ramifications of women's empowerment, that is the transformation of gender relations, into gender planning" (Wieringa, 1994) in policies and programmes required for sustainable development. Furthermore, this article aligns the concept of women empowerment with IT/ICT, and recognizes this linkage as having "the potential to advance women economically", which may well be "the most exciting transformative feature of technology ... [because] empowering women and improving the efficiency of their work is critical for reducing poverty" (Gill et al, 2012).

According to Gillard et al (2007), the "IT/ICT workforce is a fairly new professional sector, particularly in many developing countries, yet women occupy a minority of positions and gender inequalities that are well established in many other sectors are being replicated in the IT/ICT industries" (p.10). While there is recognition of the potential of ICT as a tool for the promotion of gender equality and the empowerment of women, a 'gender divide' has also been identified, reflected in the lower number of women accessing and using ICT compared with men. Unless this gender divide is specifically addressed, there is a risk that ICT may exacerbate existing inequalities between women and men and create new forms of inequality (Sandys, 2005).

Studies have revealed the fact that there is still "a common trend of male dominance of ICTs across the globe (Formatex, 2006; NDP, 2007; Hafkin, 2003; Maleka, 2011). This is particularly prevalent in developing countries on the African continent. Due to the fact that "technology is seen as gender-neutral" (Maleka, 2011, p.43) there is a lack of coherent research practice to analyze gender disparities in ICTs across human levels of interaction (Fialova, 2006). Although technological advancements have created opportunities for social and economic development, "their use continues to be governed by existing power relations where women frequently experience relative disadvantage" (Institute of Development Studies, 2013). Significant concerns can be raised in this regard, namely: "Who benefits from ICTs? Who is dictating the course of ICTs? Is it possible to harness ICTs to serve larger goals of equality and justice? Central to these concerns is the issue of gender and women's equal right to access, use and shape ICTs" (Gurumurthy, 2004, p.1). Technological progression can enhance women's empowerment by offering them opportunities in IT-driven jobs, thereby promoting the "feminisation of employment" (Howcroft \& Richardson, 2007). Yet there are vastly exaggerated claims about the likely 'impact' of new technologies on social, economic, cultural and working lives (Huws, 2003; Woolgar, 2002; Gillard et al., 2007). In many societies, because of traditional role patterns, there are frequently clear obstacles which mean that women and men do not benefit equally from the advantages of technological progress (Elsaadani, 2012). This is clearly witnessed in situations where "women and men have different needs and constraints when accessing and using ICT". The World Bank Group (2013) points out that in many societies, "women's and men's access to and use of technology are rooted in behavioral, cultural, and religious traditions" (p.3). Such circumstances may confine women exclusively to household activities, making them financially dependent on men and excluding them from decision-making processes.

It is evident that "policy-making in technological fields often ignores the needs, requirements, and aspirations of women unless gender analysis is included" (Hafkin, 2002). A recent study of hundreds of development projects, either with ICT as the major sector or with substantial ICT components, showed that "more than one-third of all projects had a high degree of awareness of gender issues, but that the gender-sensitivity carried over to the ICT components in only 10 percent of the projects" (p.4).

In order to find solutions to meet these challenges and address or mitigate them, issues of gender in the ICT domain were explored globally at the World Summit on the Information Society (WSIS), held in Geneva in 2003. The following areas were discussed as possible plans of action (compiled from WSIS, 2003):

- Action is required to remove the gender barriers to ICT education and training and promote equal training opportunities in ICT-related fields for women and girls. Early intervention programmes in science and technology should target young girls with the aim of increasing the number of women in ICT careers. The exchange of best practices on the integration of gender perspectives in ICT education should be promoted (11 (g)).

- It is imperative that programmes focus on gender-sensitive curricula in formal and non-formal education for all. Enhancement of communication and media literacy for women with a view to building the capacity of girls and women to understand and to develop ICT content is another important objective (23 (h)).

- In co-operation with each country concerned, there is a need to develop and launch a composite ICT Development Index (Digital Opportunity Index). This could be published annually, or every two years, in an ICT Development Report. The index could show the statistics while the report would present analytical work on policies and their implementation, including gender analysis, depending on national circumstances (28 (a)).

- Gender-specific indicators on ICT use and needs should be developed, and measurable performance 
indicators should be identified to assess the impact of funded ICT projects on the lives of women and girls (28 (d)).

This international exploration of bringing a gender aspect into the arena of ICT is a significant consideration for women empowerment and sustainable development. Because this discussion raised some particularly valid concerns, the issue was placed on the agenda for the second phase of WSIS, held in Tunis in 2005. These efforts resulted in the establishment of the WSIS Gender Caucus, which has a number of important objectives, among which are to (compiled from WSIS Gender Caucus, 2003):

- acknowledge gender equality and women's rights as cross-cutting principles;

- include women as leaders and decision-makers in all planning processes for the Summit and recognize that women's perspectives can make a significant contribution to aligning the Summit with the Millennium Development Goals;

- develop projects that will collect and analyze appropriate gender specific data and reporting mechanisms to evaluate and monitor the impact of ICT developments on women and girls;

- implement an information dissemination campaign that includes a wide range of media such as radio, drama and print and a variety of languages; and

- commission a study on the interaction between gender equality and ICT, which should include development of a gender equality and ICT baseline study, indicators, conceptual tools and case studies on the impact of ICT on achieving gender equality, to inform the dialogue of the Summit.

Despite all these efforts, it is (officially) recorded and witnessed that in African countries, especially the francophone countries, women are deprived of information facilities and other communication devices and. hence they experience significant ICT challenges. This has led to what can be described as a digital divide based on gender. In terms of the MDGs and sustainable development, these countries are experiencing a 'gender-based digital divide' in which women are 'digitally deprived'. To bridge this gap, the WSIS Gender Caucus has opened the opportunity for African organizations to list their representations as groups that are concerned about gender equality. Some of the significant names on this list are: ABANTU for Development; the African Connection Programme; AMARC Africa; APC Africa Women's Programme; Network of African Women Economists; Zimbabwe Ministry of Transport and Communications, to name but a few. In the case of West Africa, UNDP/SURF West Africa is also registered as a participant organization.

\section{Gender and ICT: Overview of the African Continent}

Schapera (cited in Vyas-Doorgapersad and Lukamba, 2011, p.95) has observed that before the era of Christianity (pre-42 $\mathrm{BC}$ ), men dominated the intellectual world and women had no legal status; they were at the mercy of their male relatives and husbands; a woman's destiny was marriage and motherhood. As Guy (1990) puts it, women in Africa were "precious objects of exchange and control"(p.33). In order to fight for the rights of women, and advance women empowerment globally, the feminist movements were instrumental in the compilation and implementation of the Universal Declaration of Human Rights (1948); the Convention on the Political Rights of Women (1952); the Civil and Political Rights International Act (1966); and the Convention for the Elimination of All Forms of Discrimination against Women (1979). The African continent was faced with significant global pressure and this resulted in an addendum being added to the African Charter on Human and People's Rights, known as the Protocol on the Rights of Women in Africa. The Charter was adopted by the African Union (AU) in 2003, followed by the Declaration on Gender Equality in Africa, adopted in 2004.

In addition, the Millennium Development Goals were drawn up to advance development in under-developed countries. The significance of MDG 3 is identified in the report entitled African Common Position on the Review of the Millennium Declaration and the Millennium Development Goals (African Union, 2006), stating that "the promotion of gender equality and empowerment of women is vital to achieving sustainable development. Generally, in Africa, women continue to suffer deep and systematic discrimination and exclusion. They also have less representation in political leadership and decision-making process. As a prerequisite for sustainable development, African governments need to address gender imbalances through the promotion of gender equality and empowerment of women". This statement is furthermore substantiated with an added justification by Professor Clement Dzidonu (2002) claiming that African countries, "as part of their efforts to achieve the MDGs through the use of ICTs must take steps to identify and address those critical success factors that will ensure progress towards achieving these developmental goals" (p.36).

Along with the bi-lateral and multi-lateral treaties and international agreements, regional African governments must ensure that gender equality interventions are made at both policy and personal levels. After all, "if African women do not 
take advantage of the opportunity offered by ICTs to 'catch up' technologically, they will find themselves further marginalized" (cited in Huyer and Sikoska, 2003, p.5).

\section{Gender and the Millennium Development Goals (Goals 3 and 8 ) in West Africa}

West Africa (also known as the western part of Africa or Western Africa) incorporates a number of countries, namely Benin, Burkina Faso, Ivory Coast, Cape Verde, Gambia, Ghana, Guinea, Liberia, Mali, Mauritania, Nigeria, Senegal, Sierra Leone and Togo. These countries have faced the ordeals of conflict, war, and dictatorship. In order to bring peace and enhance development, the United Nations Security Council Resolution 1325 was adopted in 2000, whereby the significant involvement of women was considered in social restructuring. This feminist reform resulted in the establishment of the Women in Peace-building Network (WIPNET) across West Africa. The Economic Commission of West African States (ECOWAS) confirmed (United Nations Economic Commission for Africa Sub-Regional Office for West Africa, 2012), "the cross-cutting nature of gender [and with] a major move to provide the necessary structures and frameworks for gender mainstreaming, ECOWAS established a Gender Development Center in 2003" (p.11). The success of this initiative correspondingly led the way towards the institutionalization of Women Peace and Security Network-Africa (WIPSEN-Africa) in 2006. All these "efforts were strengthened by the adoption of the gender policy document to mainstream gender in the sub-region and empower women" (p. 11).

The main function of gender-based empowerment structure(s) is to "mainstream gender in all legislation, government policy and planning. However, although the legal and political environments can be regarded as enabling of gender equality, the biggest challenge is the implementation of programmes aimed at attaining this goal" (Isaacs, 2007, p. 7). In the case of West Africa, the report entitled Tracking progress in the implementation of regional and international agendas, including NEPAD and other special initiatives in the sub-region to promote gender equality and empower women: MDG 3, released by the UN Economic Commission for Africa Sub-Regional Office for West Africa ECA/SRO-WA (2012) states that "although periodic monitoring of implementation suggests considerable progress registered in attaining some of the indicators, and the potential in others, challenges still persist and could jeopardize meeting the set target date of 2015" (p.13). The report stresses that poverty remains widespread, mainly because of the dearth of economic opportunities. This is the basic reason why women in West Africa are caught up in a "vicious circle deepening the already critical access to health, education, and political participation". The report on MDG 2013: Assessing Progress in Africa toward the Millennium Development Goals - Food security in Africa: Issues, challenges and lessons (a collaborative effort by the African Union Commission (AUC), the United Nations Economic Commission for Africa (ECA), the African Development Bank (AfDB) and the United Nations Development Programme (UNDP), 2013), states that although the progress towards achievement of MDG 3 in West African countries is fairly significant, "cultural practices (including inequitable inheritance practices in a few countries, early marriages and household power dynamics), low economic opportunities for women and limited political involvement continue to impede progress in meeting this goal" (p.47). The report goes on to stress that if there is to be an improvement in this parlous situation, there must be cultural transformation to reverse the "negative attitudes" towards gender equality and women's empowerment. Policy changes must be made to address all aspects of gender discrimination in the public education system and women must be afforded sustainable economic opportunities. In other words, there must be "increased participation of women in productive and remunerative economic activities" and women's voices must be heard loud and clear in decision-making "at all levels of society".

In order to align MDG 3 and MDG 8, a Gender and ICT Network has been established in West Africa. This network is a collaborative effort at global and regional levels, comprising the Environmental Development Action in the Third World (ENDA) [an international body]; the Monitoring Centre for Information Systems and the Internet in Senegal (l' Observatoire des Systèmes d'Information sur les Réseaux et Inforoutes du Sénégal - OSIRIS); and the Senegalese Telecommunications Regulations Agency (l' Agence sénégalaise de Régulation des Télécommunications - ART) [which are regional bodies]. The aim of the network is to bring gender issues into the ICT sector. To analyse the significance of ICTs (MDG 8) for fulfilling the objectives of MDG 3, a research initiative was conducted by the Gender and ICT Network [Regentic] in West Africa. The research covered countries like Benin, Burkina Faso, Cameroon, Mali, Mauritania and Senegal [the francophone countries]. The research was sponsored by the International Development Research Centre. The findings of the research are presented below in summary form (compiled from Hafkin and Huyer, 2007):

- There is a gender digital divide in the six francophone countries in Africa. The composite indicator of women's participation in information technology circles is a mere 0.65 , meaning that women have $35 \%$ fewer opportunities and benefits than men with regard to ICT.

- In these African countries men have developed a level of skills in the use of computers in the jobs they hold; 
the women tend to work at entry-level positions and while they are educated in computer use, the training provided tends to be at elementary level. These young women were not involved in creating electronic texts or using computers at a more advanced level. Women are not involved at all in developing ICT systems.

- While young women who are secondary school graduates have become the majority of those working in the ICT sphere in these countries, they tend to remain at the level of users and do not become managers or technical analysts. They gain computer skills as an entry tool for secretarial or data-entry jobs but rarely advance beyond this level.

- Very little local content is available in the francophone countries on gender issues.

- $\quad$ Few people are aware of gender issues in ICT (p.31-33).

This research initiative in West Africa incorporates sections exploring '"Sustainable Development Policies'... concerned with the necessity, at the dawn of the information society, for the inclusion of gender issues in ICT policies, ... [and the] 'Development of Relevant Indicators' which relates to the method used to determine how to evaluate and measure the gender situation in the ICT sector". The author maintains that there were "a multitude of inequalities" that came to the fore in the on-site research. The final section provides a "composite analysis of this data, and suggests action plans for the promotion of 'gender equality in the African information society'" (Mottin-Sylla, 2005, p.22).

Another research project was conducted which links MDG 3 and 8. This study is entitled ICTs and gender in primary and secondary education in West and Central Africa. The research was undertaken in the years 2004-2005 in 40 primary and secondary schools. The results indicate that "at school, priority ICTs access was given to the most motivated pupils, regardless of sex, although the boys seemed to have more access to computers outside of school, e.g., at cybercafés. Some teachers remarked that in terms of handling computer tools, in general, the boys seemed to have mastered the computer better than the girls. In most cases, a few boys were labelled 'ICT experts' by their friends" (cited in PanAfrican Research Agenda (PanAf), 2009, p.66). Another research initiative that is cited in the PanAfrican Research Agenda on the Pedagogical Integration of ICTS: Phase 2, reveals that "the problem is exacerbated by the fact that girls appear to be alienated by ICTs, considering them as belonging to the masculine realm". A similar investigation of "computer savvy" among university students indicated that female students were less skilled in the use of information technologies than their male counterparts (p.66).

\section{Conclusion and Policy Recommendations}

In order to bring gender equality and equity into the ICT sector, it is vital to consider the existing challenges and policy gaps and to find solutions for improvement. This section explores some of the significant challenges regarding gender and ICT and tries to make relevant policy recommendations for implementation in West African countries.

In Benin, the reason for lack of gender involvement in the information and technology sector is the shortage of educational resources. The country is currently in a process to "narrow the gender literacy gap (47.9\% for males and 23.3\% for females in 2002)" (e-learning Africa news portal, 2014). A study on gender equity in ICT in Burkina Faso, "published by Sylvestre Ouédraogo in September 2000" (Fall, 2007, p.7) indicated that "the Internet users polled were mainly men (68.7\%)" (p.7). In Cape Verde, the government has obtained the assistance of private sector to establish IT centres, but, in reality, "only an insignificant fraction of the population can use these services because the majority of families are poor. Added to this, the rural areas are not served at all. Currently the 20 cyber cafés on the islands are restricted to Praia and Mindelo with little else on the other islands" (Agyeman, 2007, p.7). An exploratory study conducted by the Panos Institute West Africa (PIWA) and the United Nations Development Programme (UNDP) in 2009 covered the countries Côte d'Ivoire, Ghana, and Senegal. The aim was to explore gender inequalities that "are particularly reflected at an economic level, with strong disparities between the incomes of men and women. It seems that in many cases, women are not only excluded from equal social and economic opportunities but also from the benefits offered by ICT, from access to new technologies and from a place within the information society" (Fraser-Moleketi \& Senghor, undated, p.25).

According to the Republic of Gambia: Programme for Accelerated Growth and Employment [PAGE] 2012-2015 (Ministry of Finance and Economic Affairs, 2012), "Gambia is a patriarchal society characterized by male hegemony and other socio-cultural factors that interplay to influence the interactions between the genders and social groups" (p.112). In some cases these inequalities have led to the exclusion of women and girls, from "actively participating in the development process of the country. Overall, gender responsiveness in Gambia is, low" (p.112).

Women "represent less than 10 per cent of the Internet users in Guinea" (United Nations Conference on Trade and Development: Information Economy Report 2006, p.169). There is a similar scenario in Liberia. According to the Republic of Liberia Agenda for Transformation: steps towards Liberia rising 2030 (undated), "the culture of patriarchy pervades Liberian society, beginning in the family with men as heads of households, and serves as the model for organizing society 
- its economy, politics and socio-cultural life" (p.126). Similarly, in Mali, a better understanding of the "interplay of information and communication technology (ICT) and the role of women in facilitating social, political and economic development" is needed. Mali is described as a least developed country (LDC). Women in this country face the unenviable prospect of "low literacy rates, high birth rates, high infant and maternal mortality rates, and low incomes ... The benefits of ICT development [and its integration] with gender equity would go a long way to inform "policymakers' understanding of ICT diffusion and its benefits to people in LDCs" (Dumas, 2008).

In general, women have one chance in three less than men of benefiting from the African information society in Mauritania (Biztech Africa, 2012). It appears that the ICTs are seen as tools for transformation and are expected to change the status quo. One cannot but wonder just how many African women in rural communities can access ICTs services.

In Nigeria, there are no libraries or information centres in rural areas (Jorge, 2002), while ICT infrastructure in Sierra Leone is in dire need of reform (World Bank, 2005; Government of Sierra Leone, 2005; US Department of State, 2003; United Nations Conference on Trade and Development: Information Economy Report 2006). According to Agyeman-Duahl (2007) Togo has no official ICT policy (p.4).

Based on the challenges explored above, this article proposes the following recommendations to be included in policy documents:

- Policy documents must accommodate the provision of free education for girls. This will improve female enrolment at institutes of learning. Furthermore, the utilization of e-learning processes can enhance the level of technological skills among female learners. This will, in the future, bring technological transformation and the socio-economic advancement of women in society.

- In order to improve the gender-based technologically enhanced skilled force, West African governments need to engage the stakeholders (men and women) from public and private sectors to discuss the varied roles for mutual benefit.

- To accommodate gender issues in the ICT policy, research on gender disaggregated data is imperative to identify the varied roles, responsibilities and requirements of men and women.

- Gender policies must be aligned with ICT policies in a cross-cutting manner, linking the development aspect of education and training in an e-environment for improved technological development of girl/women learners.

- Political will is a vital component to structure legislative measures that accommodate gender equality in the ICT sector.

- Capacity-building initiatives must be established for gender-based training for ICT.

- Gender-based ICT training for women empowerment needs an individual vote in the budget statements.

- Monitoring and evaluation procedures need to be established for quality evaluation, review and sustainability of gender-based ICT for development.

In addition it is recommended that policy documents incorporate the establishment of one-stop call centres in the rural areas. Once these centres are in place, community development workers should be deployed to educate women in regional/local language(s). The West African governments need a dual approach: first, to improve the ratio of girls/boys education in the schools for gender balance and equity (MDG 3), and secondly, to incorporate ICT in the school curricula at educational and vocational levels (MDG 8). Incorporation of capacity-building programmes in national policies; investment in girls' education; provision in the budget for ICT training at country-specific levels; and introducing financial opportunities for women in technologically enriched IT jobs, will assist West African countries to achieve women empowerment (MDG 3) in ICT sector (MDG 8), and to gain an understanding of the empowerment approach utilized as a theoretical framework in this article.

In order to address the challenges facing women empowerment in the African continent as a whole, the APCAfrica-Women network has been set up for aligning MDG 3 with MDG 8. It is a network of varied institutions and individual stakeholders aiming to empower African women's organisations through the access and utilization of ICTs, thereby working towards gender equity and equality. APC-Africa-Women network is a part of the Africa regional programme of APC's Women's Networking Support Programme (APCWNSP). Another initiative is Africa: African Women's Development and Communications Network (FEMNET), which aims to promote the development of African women.

A close examination of the available literature and official reports reveals that although certain West African countries such as Ghana, Sierra Leone and Liberia are in a position to achieve MDG 3 and 8 (albeit it only to some extent), the same cannot be said of other countries, notably Mali, Guinea Bissau and Cote d'Ivoire. These three West African countries are still struggling under dictatorships, political uncertainty, poor leadership and weak governance. 
Indeed, at this point in time, the road ahead to achievement of these MDGs is particularly demanding and challenging.

\section{References}

Agyeman, T.O. (2007). ICT in Education in Cape Verde: survey of ICT and education in Africa: Cape Verde Country Report. Retrieved on April 10, 2012 from http://www.infodev.org/infodev-files/resource/InfodevDocuments_354.pdf.

Agyeman-Duahl, O. (2007). ICT in Education in Togo: survey of ICT and education in Africa: Togo Country Report. Retrieved on March 25, 2013 from http://www.infodev.org/infodev-files/resource/InfodevDocuments_433.pdf.

African Union. (2006). African Common Position on the Review of the Millennium Declaration and the Millennium Development Goals. Ethiopia: Addis Ababa.

Balit, S. (1999). Voice for change: rural women and communication. Rome: Food and Agriculture Organization.

BiztechAfrica. (2012). Gender ICT divide worsens in Senegal. Retrieved on March 23, 2013 from http://www.biztechafrica.com/article/gender-ict-divide-worsens-senegal/4873/\#.Ut0OzuKxUdU.

Cherry, K, (2013). What is gender? Retrieved on April 06, 2014 from http://psychology.about.com/od/gindex/g/gender.htm.

Dhoj, I. (2009). Gender and Communication: Critical Assessment on Theories on Gender Development. Regional Master Programme. Bangladesh: Dhaka University.

Dumas, J. A. (2008). Gender ICT and Millennium Development Goals. Retrieved on June 24, 2013 from http://www.igiglobal.com/chapter/gender-ict-millennium-development-goals/22685.

Dzidonu, C.K. (2002). A Framework for Guiding the Development of ICT-led Socio-Economic Development Policies, Strategies and Plans, Special Working Paper Series No.5. Nairobi, Kenya: Africa Technology Policy Study (ATPS).

e-learning Africa news portal. (2014). eLearning and sustainable development: perspectives from Benin. Retrieved on March 15, 2014 from http://www.elearning-africa.com/eLA Newsportal/elearning-and-sustainable-development-perspectives-from-benin/.

Economic Commission ECA for Africa. (2012). Tracking progress in the implementation of regional and international agendas, including NEPAD and other special initiatives in the sub-region promote gender equality and empower women: MDG 3. Niger: United Nations Economic Commission for Africa Sub-Regional Office for West Africa ECA/SRO-WA.

Elsaadani, M. (2012). Teaching staff attitude toward ICT: Is Gender a Factor? International Women Online Journal of Distance Education July, 1 (2), 1-10.

Fall, B. (2007). ICT in Education in Burkino Faso. Retrieved on August 26, 2013 from

http://www.infodev.org/infodev-files/resource/InfodevDocuments 388.pdf.

Fialova, K. (2006). Associating gender with ICT policy: Association for Progressive Communications Women's Networking Support Programme. Retrieved on March 17, 2013 from http://www.i4donline.net/articles/current.article.asp?articleid=590\&typ=Features.

Formatex. (2006). Examining the level of penetration and impact of Internet usage amongst undergraduates in Nigerian Universities - a case study approach. Retrieved on April 18, 2012 from http://www.researchgate.net/publication 1235959521_Examining_levels_of_penetration and impacts_of_internet_usage_amongst_undergraduates_in_Nigerian_Universities: a_case_study_approach.

Fraser-Moleketi, G. and Senghor, D. (undated). E-governance and Citizen Participation in West Africa: Challenges and Opportunities. New York: UNDP in collaboration with PIWA-West Africa.

Gill, K., Brooks, K., McDougall, J., Patel, P. \& Kes, A. (2012). Bridging the gender divide: how technology can advance women economically. UK: International Centre for Research on Women (ICRW).

Gillard, H., Howcroft, D., Mitev, N. \& Richardson, H. (2007). 'Missing Women': Gender, ICTs and the Shaping of the Global Economy. UK: Centre for Research on Socio-Cultural Change (CRESC).

Gillard, H., Howcroft, D., Mitev, N. \& Richardson, H. (2008). 'Missing women': gender, ICTs, and the shaping of the global economy. Information Technology for Development, 14 (4), 262-279.

Govender, S.D. and Vyas-Doorgapersad, S. (2013). The implementation of gender equality policies in achieving millennium development goal three in the Sedibeng District Municipality. Journal of Public Administration, 8 (1),105-117.

Government of Sierra Leone. (2005). Poverty Reduction Strategy Paper. Retrieved on April 19, 2013 from https://www.imf.org/external/pubs/ft/scr/2005/cr05191.pdf.

Gurumurthy, A. (2004).Gender and ICTs: Overview Report. Institute of Development Studies September 2004. Retrieved on July 27, 2013 from http://www.unesco.org/new/fileadmin/MULTIMEDIA/HQ/SHS/pdf/Gender-ICTs.pdf.

Guy, J. (1990). Gender oppression in Southern Africa's pre-capitalist societies, in C. Walker (ed.), Women and gender in Southern Africa. London: James Currey and David Philip, 1990, 33-48.

Hafkin, N.J. (2003). Gender Issues in ICT Statistics and Indicators with Particular Emphasis on Developing Countries. Paper presented at the Joint UNICE/UNCTAD/ITU/EUROSTAT Statistical Workshop. Geneva.

Hafkin, N. (2002). Gender Issues in ICT Policy in Developing Countries: An Overview. Paper presented during the Expert Group Meeting on "Information and communication technologies and their impact on and use as an instrument for the advancement and empowerment of women. Seoul, Republic of Korea 11 to 14 November 2002.

Hafkin, N. and Taggart, N. (2001). Gender, information technology, and developing countries: an analytical study. Washington, DC: Academy for Educational Development.

Hafkin, N.J. and Huyer, S. (2007). Women and Gender in ICT Statistics and Indicators for Development. Information Technologies and International Development, 4 (2), 25-41. 
Howcroft, D. and Richardson, H. (2007). Gender Matters in the Global Outsourcing of Service Work. UK Centre for Research on SocioCultural Change (CRESC).

Huws, U. (2003). The Making of a Cybertariat: Virtual Work in a Real World. London: Merlin Press.

Huyer, S. and Sikoska, T. (2003). Overcoming the Gender Digital Divide: Understanding ICTs and their Potential for the Empowerment of Women. INSTRAW Research Paper Series No. 1. Retrieved on July 27, 2012 from http://www.iiav.nl/epublications /2003/Overcoming.pdf.

Institute of Development Studies. (2013). BRIDGE Cutting Edge Packs Gender and ICTs. Retrieved on May 15, 2014 from http://www.bridge.ids.ac.uk.

Isaac, S. (2007). Survey of ICT and education in Africa: South Africa Country Report South Africa - 1. Retrieved on June 17, 2013 from http://www.infodev.org.

Jensen, S.C. (1989). Gender and the information society: a socially structured silence. Journal of Communication, 39 (3), $196-215$.

Jorge, S.N. (2002). The Economics of ICT: Challenges and Practical strategies of ICT use for Women's Economic Empowerment. Paper presented at the "Information and communication technologies and their impact on and use as an instrument for the advancement and empowerment of women. Seoul, Republic of Korea 11 to 14 November 2002.

Lars, J. (2003). The role of men and boys in achieving gender equality. New York: New York Press.

Mackinnon, C. (1989). Toward a Feminist Theory of the State. Cambridge: Harvard University Press.

Maleka, M.B.M. (2011). A gender-based analysis of ICT adoption and usage in South Africa. A research report. University of the Witwatersrand: Faculty of Management.

Molyneux, M. (1985). Mobilization without emancipation? Women's Interests, the State, and Revolution in Nicaragua. Feminist Studies, $11(2), 227-254$.

Moser, C.O.N. (1993). Gender Planning and Development: Theory, Practice and Training. London and New York: Routledge.

Mottin-Sylla, M.H. (2005). The Gender Digital Divide in Francophone Africa: A Harsh Reality. Dakar: ENDA.

Mpow.org. (2012).Developing a Theory of Empowerment: in search of a meta-theory. Retrieved on August 17, 2013 from http://www.mpow.org.

NDP (National Development Plan), (2007). Gender Equality in IT, Ecommerce and Internet Usage. Retrieved on March 13, 2014 from http://ndpgenderequality.ie/downloads/factsheets/it\&internet.pdf.

PanAfrican Research Agenda (PanAf). (2009). PanAfrican Research Agenda on the Pedagogical Integration of ICTs: Phase 2. Retrieved on July 27, 2013 from http://www.observatoiretic.org/documents/IDRC-PHASE2-EN-All.pdf.

Reddy, P.S. (2006). A Strategic Framework for Gender Equality within the Public Service (2006-2015): a consultation document. Pretoria: Department of Public Service and Administration.

Rubin, G. (1975). 'The Traffic in Women: Notes on the "Political Economy" of Sex', in R. Reiter (ed.), Toward an Anthropology of Women. New York: Monthly Review Press: 157-210.

Sandys, E. (2005). Gender equality and empowerment of women through ICT: women 2000 and beyond. September 2005. United Nations: Division for the Advancement of Women Department of Economic and Social Affairs.

The African Union Commission (AUC), the United Nations Economic Commission for Africa (ECA), the African Development Bank (AfDB) and the United Nations Development Programme (UNDP). (2013). MDG 2013: Assessing Progress in Africa toward the Millennium Development Goals - Food security in Africa: Issues, challenges and lessons. Retrieved on February 15, 2014 from http://www.afdb.org/fileadmin/uploads/afdb/Documents/Publications/Millennium\%20Development\%20Goals\%20(MDGs)\%20Rep ort\%202013.pdf.

The Republic of Liberia. (undated). Agenda for Transformation: steps towards Liberia rising 2030. Retrieved on November 19, 2013 from http://mof.gov.Ir/doc/AfT\%20document-\%20April\%2015,\%202013.pdf.

The Republic of the Gambia. (2012). Programme for Accelerated Growth and Employment [PAGE] 2012- 2015. Gambia: Ministry of Finance and Economic Affairs.

The World Bank Group. (2013). Key Issues on Gender and Development. Retrieved on October 27, 2013 from http:/lgo.worldbank.org/JY9AZO39Z0.

United Nations. (2006). United Nations Conference on Trade and Development: Information Economy Report. Retrieved on June 24, 2013 from http://unctad.org/en/docs/sdteecb20061ch3 en.pdf.

US Department of State. (2003). Sierra Leone. Country Reports on Human Rights Practices 2002. US: Bureau of Democracy, Human Rights, and Labor.

Vyas-Doorgapersad, S. and Lukamba, T.M. (2011). The status and political participation of women in the Democratic Republic of Congo (1960-2010): A critical historical reflection New Contree, No. 62, 91-110.

Wieringa, S. (1994). Women's Interests and Empowerment: Gender Planning Reconsidered. Development and Change, 25, 829-848.

Wikibooks. (2013). Gender and ICT/Placing Women's Empowerment: Back into the Gender Equality Framework. Retrieved on December 5 , 2013 from http://en.wikibooks.org/wiki/Gender_and ICT/Placing_Women\%27s_Empowerment_Back_Into the_Gender_Equality_Framework.

Woolgar, S. (2002). Five rules of virtuality in Virtual Society? Technology, Cyberbole, Reality. Oxford: Oxford University Press, 1-22.

World Bank. (2005). Republic of Sierra Leone (Joint IDA-IMF Staff Advisory Note on the Poverty Reduction Strategy Paper. Washington, DC: World Bank.

World Summit on the Information Society (WSIS). (2003). Plan of action. Retrieved on November 7, 2013 from http://www.itu.int/wsis/ docs/geneva/official/poa.htm.

WSIS Gender Caucus. (2003). About us. Retrieved on November 16, 2013 from http://www.genderwsis.org/aboutus.0.html. 